\title{
Implementasi Metode Active Debate Learning \\ Pada Pembelajaran Pendidikan Agama Islam \\ Di Sekolah Menengah Kejuruan ( SMK ) Nurul Huda Sukaraja Kabupaten Ogan Komering Ulu Timur
}

\author{
Sirot Julmuntolib ${ }^{1^{*}}$ Muhamad Ikhsanudin ${ }^{2^{*}}$ \\ 1,2* STKIP NURUL HUDA SUKARAJA \\ Email : ikhsanudin@stkipnurulhuda.ac.id
}

\begin{abstract}
Abstrak
Di dalam dunia Pendidikan, Pembelajaran akan ketinggalan zaman apabila masih memposisikan pengajar (guru) sebagai pusat segala-galanya (teacher oriented). Tetapi pembelajaran harus menjadikan siswa sebagai subyek (actor) pembelajaran yaitu pembelajaran berbasis pada siswa (active learning).
\end{abstract}

Diantara satu metode pembelajran berbasis active learning adalah metode active debate learning. Oleh karena itu pokus pemasalahannya Sebagai berikut: Bagaimanakah persiapan metode active debate learning dalam pembelajaran pendidikan agama Islam. Bagaimanakah pelaksanaan metode active debate learning dalam pembelajaran pendidikan agama Islam. Apakah faktor pendukung dan penghambat penerapan metode active debate learning dalam pendidikan agama Islam berlokasi di SMK Nurul Huda Sukaraja dengan tujuan mendeskripsikan implementasi metode active debate learning pada pembelajaran pendidikan agama Islam di SMK Nurul Huda Sukaraja

Penelitian ini menggunakan pendekatan deskriptif kualitatif yang bertujuan untuk mendeskripsikan dan menginterpretasikan objek penelitian sesuai dengan apa adanya, dalam bentuk kata-kata tanpa menggunakan rumus-rumus berdasarkan angka-angka. Dengan menggunakan alat pengumpul data Obsesvasi, wawancara dan dokumentasi. Setelah itu di analisis dengan menggunakan analisis deskriptif, karena bertujuan untuk mendeskripsikan implemantasi metode active debate learning pada pembelajaran pendidikan agam Islam di SMK Nurul Huda Sukaraja.

Dari teori ini dapat di tarik suatu kesimpulan, Pertama, Kedua Guru Pendidikan Agama Islam pada ketiga kelas yang diteliti, sebelum mengajar telah mempersiapkan kegiatan pembelajaran dengan berbagai aktifitas seperti membuat perangkat pembelajaran meliputi; Program Tahunan (Prota), Program Semester (Promes), Rencana Pelaksanaan Pembelajaran (RPP) dan bahan ajar yang akan diperdebatkan di kelas. Kedua. Dalam pelaksanaan pembelajaran, pada aspek Tarikh dan SKI di kelas XII Administrasi Perkanntoran dibagi ke dalam tiga kelompok yaitu pro/penyaji, kontra dan pembela. kelompok penyaji bertugas menyampaikan materi dan di tanggapi oleh kelompok kontra dan kelompok pembela bertugas untuk meluruskan jalannya perdebatan, begitu juga pada aspek Akhlak di kelas XI Multimedia dan aspek Akidah di kelas X Akuntansi. Dalam mengevaluasi kedua guru Pendidikan Agama Islam tersebut sudah cukup baik, karena sudah menggunakan instrumen dalam pola yang baru yaitu instrumen soal uraian tertulis untuk menilai aspek kognitif, instrumen pengamatan sikap dan minat untuk menilai aspek afektif dan instrumen penugasan untuk menilai aspek psikomotorik. Ketiga. 
Faktor pendukung dalam pelaksanaan metode Active Debate ini barasal dari 'guru, siswa dan sarana prasarana'. Kedua guru Pendidikan Agama Islam sudah tersertifikasi sehingga keduanya sudah sering mendapatkan diklat tentang pembelajaran, semua siswa sudah terbiasa dengan debat tatkala belajar diasrama, 'Sarana prasarana' terutama bangku dan meja yang mudah di susun dalam formasi debate dan didukung adanya waifi, materi pelajaran didukung dari pelajaran yang diajarkan dipesantren, dan metode yang di gunakan di pesantren adalah metode sawir (musyawarah) juga bisa di katakana metode Devate. Dan faktor penghambat dalam pelaksanaan metode debat aktif ini adalah tidak semua guru mendukung, tidak ada respon yang positif dari pengurus yayasan dan adanya intimidasi dari siswa yang merasa tersudut.

Berdasarkan hasil penelitian direkomendasikan pada peneliti untuk melanjutkan penelitian ini dan kepada pengelola sekolah (Kepala sekolah dan guru) agar tidak melakukan pembelajaran monoton di dalam kelas saja, tetapi memanfaatkan ruang multimedia dengan segala fasilitasnya, bahkan bila perlu di luar kelas.

Kata Kunci : Implementasi, Metode, Active Debate, Pendidikan, Islam.

\section{PENDAHULUAN}

Pembelajaran pada hakikatnya bermuara kepada peserta didik, maka diperlukan suatu sistem lingkungan yang mendukung tercapainya tujuan pembelajaran itu. Sistem lingkungan yang penulis maksudkan adalah adanya strategi dan metode pembelajaran yang tepat untuk diaplikasikan dalam kegiatan pembelajaran dengan menjadikan siswa sebagai subjek (aktor) bukan semata-mata sebagai objek.

Menyikapi perihal tersebut, maka diperlukan strategi pembelajaran yang terarah, efektif dan efisien, agar sebuah proses pembelajaran benar-benar dapat menghasilkan peserta didik yang berkepribadian, memiliki keterampilan dalam menjalani kehidupannya dengan baik (Zamroni 2007, hlm. 228). Artinya diperlukan sebuah strategi yang tepat agar seorang guru sukses dalam proses pembelajarannya, yang akhirnya akan dapat mencapi tujuan-tujuan pembelajaran yang telah direncanakan.

Silberman (2013, hlm. 2) memodifikasi dan memperluas paham active learning sebagai pengembangan dari apa yang telah dinyatakan oleh Confucius yang disebut dengan Kredo Pembelajaran Aktif, bahwa : Ketik saya mendengar, saya lupa. Ketika saya mendengar dan melihat, saya ingat sedikit. Ketika saya mendengar, melihat, dan bertanya atau berdiskusi dengan orang lain, saya mulai mengerti. Ketika saya mendengar, melihat, berdiskusi, dan melakkukan, saya memperoleh pengetahuan dan keterampilan. Ketika saya mengajarkan kepada yang lain, saya menguasai.

Berdasarkan paham belajar aktif tersebut jelas bahwa dalam proses belajar mengajar siswa dituntut aktif dalam mencari informasi atau pengetahuan yang diinginkan, tidak hanya mendengar, melihat akan tetapi juga menanyakan, mendiskusikan, bahkan melakukan debat dan mempresentasikan pengetahuannya. 
Sementara guru memberikan bimbingan serta beberapa alternatif sumber belajar dan mengkondisikan agar semaksimal mungkin siswa belajar dengan aktif, sehingga siswa mendapatkan pengalaman sendiri yang kemudian akan mengkristal menjadi pengetahuannya. Oleh karena itu, menggunakan strategi berbasis active learning dalam pembelajaran merupakan salah satu pilihan yang sesuai dan sangat cocok dengan teori tersebut.

Active learning merupakan bentuk pembelajaran yang berorientasi pada pembentukan keaktifan siswa sejak awal melalui aktifitas-aktifitas belajar yang membangun kerja kelompok dan dalam waktu singkat membuat siswa berfikir tentang materi. Realisasinya adalah siswa dalam proses belajar bisa berperan sebagai pemimpin atau penyaji materi untuk seluruh kelas atau dalam kelompok kecil, merangsang diskusi dan debat, mempraktikkan keterampilan-keterampilan, mendorong adanya pertanyaan-pertanyaan, membuat siswa mempresentasikan ide kepada siswa yang lain, dan termasuk peserta didik saling mengajar satu sama lain. (Silberman 2001, hlm. xiv). Strategi yang disebutkan terakhir itulah yang kemudian dikenal dengan istilah starategi /metode active debate learning.

Active debate learning merupakan salah satu dari strategi pembelajaran berbasis active learning. Metode ini pada praktiknya menempatkan seluruh tanggung jawab belajar pada peserta didik sebagai anggota kelas. Siswa di dalam proses belajar mengajar diarahkan agar dapat berperan sebagai narator dan menyajikan materi yang sedang dipelajari kepada kelompok debatnya di kelas. Teknis pelaksanaan metode ini diatur oleh guru sesuai rencana pembelajaran yang tertulis pada perangkat pembelajaran guru. Untuk itu metode active debat learning harus diterapkan dalam pembelajaran pendidikan agama Islam atau pembelajaran bidang studi lainnya.

Berkaitan dengan beberapa permasalahan tersebut, penulis merasa tertarik untuk mengadakan pengkajian dalam bentuk penelitian terhadap "Impelementasi Metode Active Debate Learning Dalam Pembelajaran Pendidikan Agama Islam di SMK Nurul Huda Sukaraja".

\section{METODE/EKSPERIMEN}

Jenis penelitian dalam penulisan karya ilmiah ini adalah deskriptif kualitatif yang bertujuan untuk mendeskripsikan dan menginterpretasi objek sesuai dengan apa adanya.

\section{Pendekatan Penelitian}

Pendekatan yang digunakan dalam penelitian ini adalah pendekatan kualitatif. Pendekatan kualitatif karena data yang terkumpul berbentuk kata-kata atau gambar , sehingga tidak menekankan pada angka. (Sugiyono 2010, hlm. 22)

Penelitian kualitatif pada dasarnya adalah metode penelitian yang berlandaskan pada filsafat postpositivisme, digunakan untuk meneliti pada kondisi obyek yang alamiah, dimana peneliti sebagai instrumen kunci, teknik pengumpulan data dengan triangulasi (gabungan), analisis data bersifat induktif/kualitatif, dan hasil penelitian kualitatif lebih menekankan makna dari pada generalisasi. (Sugiyono 2008, hlm. 15). 


\section{Subyek dan Informan Penelitian}

Subjek penelitian adalah bagian yang sangat penting dalam penelitian karena subjek penelitian akan memberikan data-data yang dibutuhkan dalam penelitian..

Adapun yang menjadi subyek dalam penelitian ini adalah siswa (kelas XII Administrasi Perkantoran, Kelas XI Multimedia dan X Akutansi), guru dan sarana prasarana dalam SMK Nurul Huda Sukaraja.

Sedangkan informan dalam penelitian ini adalah siswa dalam pelaksanaan metode Pembelajaran Debat Aktif dan Guru Pendidikan Agama Islam SMK Nurul Huda. Serta sumber data lainnya adalah dokumentasi SMK Nurul Huda meliputi data tentang Letak geografis, keadaan guru dan pegawai, dan kurikulum.

\section{Jenis Data}

Jenis data dalam penelitian ini adalah data kualitatif, "data kualitatif pada umumnya dalam bentuk pernyataan kata-kata atau gambaran tentang sesuatu yang dinyatakan dalam bentuk penjelasan dengan kata-kaa atau tulisan"

(Kountur 2009, hlm. 191) dan datanya diperolah dari observasi, dan wawancara. Data-data tersebut tidak berbentuk angka tetapi berupa kategori dan kata-kata atau kalimat.

Teknik Pengumpulan Data

Karena penelitian ini merupakan penelitian deskriptif menggunakan pendekatan kualitatif, maka dalam pengumpulan data penulis menggunakan cara sebagai berikut:

a. Observasi

Observasi adalah pengamatan terhadap suatu objek yang diteliti baik secara langsung maupun secara tidak langsung untuk memperoeh data yang harus dikumpulkan dalam penelitian.

b. Wawancara

Wawancara adalah percakapan dengan maksud tertentu. Percakapan dilakukan oleh dua pihak, yaitu pewawancara yang mengajukan pertanyaan dan terwawancara yang memberi jawaban atas pertanyaan tersebut.

c. Tes

Proses pelaksanaan tes pada siswa dilakukan setelah berahirnya pembahasan satu pokok bahasan atau bias juga setelah berahirnya satu 
semester.

d. Dokumentasi

dokumentasi ditujukan untuk memperoleh data langsung dari tempat penelitian, meliputi buku-buku yang relevan, peraturan-peraturan/ laporan kegiatan, foto-foto, flim dokumennter, data yang relevan dengan penelitin.

Teknik Analisa Data.

Teknik analisa data yang digunakan adalah deskriptif naratif yaitu : 1. Reduksi data, 2. Penyajian data, dan 3. Penarikan kesimpulan/Verifikasi, ( Satori dan Komariah 2010, hlm. 221).

\section{Data Reduction ( Reduksi data )}

Mereduksi data berarti merangkum, memilih hal-hal yang pokok, mempokuskan pada hal-hal yang penting, dicari tema dan polanya dan membuang yang tidak perlu, (Sugiyono 2010, hlm. 338). Data yang di reduksi adalah data yang didapatkan dari hasil observasi, wawancara serta dokumennttasi.

\section{Data display ( penyajian data )}

Dengan mendisplaykan data, maka akan memudahkan untuk memahami apa yang terjadi, merencankan kerja selanjutnya berdasarkan pada apa yang telah dipahami tersebut, (Sugiyono 2010, hlm. 341). Artinya langkah untuk mendapatkkan suatu kesimpulan.

\section{Penarikan Kesimpulan / Verifikation}

Langkah ketiga dalam analisis data kualitatif, Kesimpulan yang diharapkan dalam penelitian kualitatif ini adalah dapat terjawabnya rumusan masalah yang ada, yakni bagaimana implementasi metode debate aktive learning pada pembelajaran pendidikan agama Islam di SMK Nurul Huda Sukaraja OKU Timur.

\section{HASIL DAN PEMBAHASAN}

langkah-langah dasar dalam pendekatan pengajaran ada tiga tahab teori, ketiga tahab teori itu adalah sebagai berikut:

1. Persiapan (Planning)

2. Penerapan (Implementing)

3. Penilaiann (Assessing) 
Persiapan Metode Active Debate Learning Pada Pembelajaran Pendidikan Agama Islam di SMK Nurul Huda Sukaraja

Metode active debate merupakan salah satu model strategi pembelajaran yang berbasis active learning, yang telah diterapkan penggunaannya di SMK Nurul Huda Sukaraja sejak ditetapkannya penggunaan kurikulum berbasis kompetensi (KBK) pada tahun 2004 lalu. Penggunaan metode debat aktif ini diterapkan pada hampir semua mata pelajaran termasuk juga pada pembelajaran mata pelajaran pendidikan agama Islam.

\section{Persiapan Pembelajaran}

Persiapan yang dilakukan oleh Pak H. Muhammad Kholil, S.Pd.I. dalam pembelajaran pendidikan agama Islam di kelas XII SMK Nurul Huda Sukaraja adalah persiapan-persiapan dalam menggunakan model pembelajaran active learning dengan jenis metode active debate (debat aktif). Sebagai seorang guru yang dituntut profesional dalam menjalankan tugas, tentunnya beliau sudah menyiapkan Rencana Persiapan Pembelajaran (RPP) yang akan di tuangkan dalam pembelajaran. Komponen-komponen yang perlu dipersipkan di dalam RPP yang berbasis KTSP adalah Standar Kompotensi, Kompetensi dasar, Menentukan Indikator, Materi pelajaran, Metode Pembelajaran, Kegiatan Pembelajaran, alokasi waktu, Sumber Belajar dan Penilaian.

Satu hal yang perlu diperhatian oleh guru dalam penerapan metode active debate adalah materi pelajaran yang dipilih bersifat kontroversial dan materi itu dibagikan kepada siswa seminggu sebelumnya. Itulah sebabnya sebelum Pak $\mathrm{H}$. Muhammad Kholil, S.Pd.I masuk kelas dan memulai pembelajaran, dia harus meyakini bahwa materi pelajaran telah diterima oleh siswa 1 (satu) minggu sebelum pembelajaran. Siswa diharuskan untuk membaca dan memahami materi itu agar memudahkan "debat".

\section{Pelaksanaan Pembelajaran}

Setelah tahap persiapan selesai dilakukan, selanjutnya penulis melakukan observasi terhadap pelaksanaan pembelajaran Pendidikan Agama Islam yang dilakukan oleh Pak H. Muhammad Kholil, S.Pd.I, selaku guru Pendidikan Agama Islam di SMK Nurul Huda Sukaraja.

Berpedoman kepada standar kopetensi, kompetensi dasar dan ketiga indikator tersebut, Pak H. Muhammad Kholil, S.Pd.I mengambil suatu isu kontorversial yang akan dijadikan sebagai tema perdebatan adalah 'Mungkinkah negara Islam didirikan di Indonesia'?

Pak H. Muhammad Kholil, S.Pd.I dengan penuh percaya diri memasuki ruang belajar sembari mengucap salam, lalu dijawab dengan serentak oleh seluruh siswa. 
Pembelajaran diawali dengan mengucap basmalah dan dilanjutkan dengan do'a bersama. Setelah memeriksa kehadiran siswa kemudian beliau menanyakan apakah seluruh siswa sudah membaca dan memahami topik atau materi yang akan diperdebatkan pada hari ini. Setelah semua siswa menjawab sudah, kemudian beliau memberikan penjelasan tentang topik atau materi pelajaran dan menjelaskan tujuan pembelajaran yang akan dicapai.

Selanjutnya beliau memerintahkan kepada siswa agar membuat 5 kelompok secara acak, dengan menghitung 1, 2, 3 sampai 5. Kemudian beliau memerintahkan siswa yang nomor 1 digabung nomor 1 sebagai kelompok satu, nomor 2 dengan nomor 2 sebagai kelompok dua dan seterusnya. Selanjutnya menetapkan kelompok satu sebagai penyaji materi atau kelompok pro, kelompok dua dan tiga sebagai kelompok kontra, kelompok empat sebagai pembela dan kelompok lima sebagai penengah.

Selanjutnya sebelum debat dimulai, Pak H. Muhammad Kholil, S.Pd.I menyampaikan dan menjelaskan materi secara global (secara garis besar) kepada seluruh siswa dalam bentuk ceramah. Kemudian beliau meminta kepada masingmasing kelompok untuk menentukan salah seorang di antara mereka sebagai juru bicara dan meminta kepada mereka untuk mendiskusikan materi ini pada kelompok mereka masing-masing, sambil mereka merumuskan argumen-argumen dari hasil diskusi mereka. Setelah itu beliau meminta setting kelas diubah. menjadi bentuk seperti di bawah ini:

Gambar 5: Setting kelas untuk debate active kelas XII

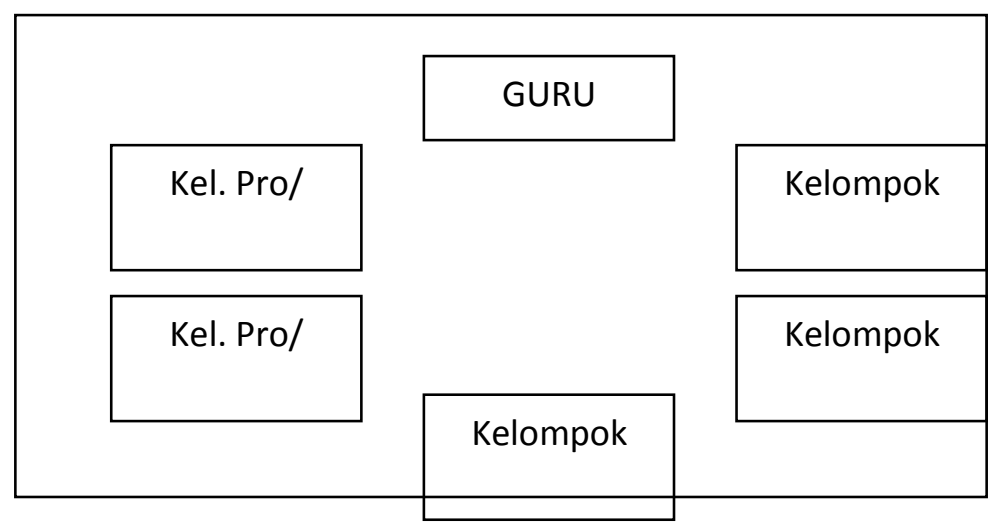

Setting kelas dibuat seperti ini, dengan maksud agar peserta didik memperoleh suasana kelas yang baru, Setting kelas tidak harus seperti di atas, tetapi seorang guru yang akan melaksanakan proses pembelajaran dengan metode debat, haruslah mengatur settingan kelas dengan berbagai variasi. Tujuan dari variasi settingan kelas tidak lain kecuali agar siswa tidak jenuh dan bosan dalam melakukan kegiatan proses pembelajaran.

Setelah setting kelas seperti di atas, beliau berperan sebagai pemandu. Langkah pertama, beliau meminta juru bicara kelompok penyaji untuk menyampaikan argumen-argumennya. Lalu A. Khalil Mustofa selaku juru bicara 
kelompok penyaji (pro) mengatakan: "Sangat mungkin negara Islam didirikan di Indonesia, dengan alasan bahwa mayoritas penduduk Indonesia adalah muslim, demikian juga hal ini pernah dilakukan oleh Rasulullah ketika di Madinah beberapa tahun yang lampau".

Langkah kedua, meminta dari juru bicara kelompok kontra untuk mengkouter argumen itu dengan argumen-argumen pula. Kelompok kontra ini diwakili oleh Lismawati sebagai juru bicara dan berpendapat bahwa "Tidak mungkin negara Islam bisa didirikan di Indonesia, sebab penduduk Indonesia bukan hanya orang Islam saja. Kalau negara Islam didirikan di Indonesia, maka agama-agama lain akan memisahkan diri dari negara ini dan akan terjadi pertikaian antar agama". Peserta didik semua bertepuk tangan untuk memberikan semangat kepada juru bicara mereka masing-masing. Pak H. Muhammad Kholil, S.Pd.I sengaja membuat debat antar kelompok penyaji dengan kelompok kontra agar suasana menjadi hangat dan sesekali meminta argumentasi dari kelompok penengah. M. Mahfud Asrori selaku juru bicara kelompok penengah mengatakan: "Marilah kita berfikir dengan jernih, masalah mungkin tidaknya negara Islam didirikan di Indonesia ini memang masalah yang rumit dan membutuh pemikiran, tenaga dan biaya, bukan sekedar ngomong ceplas-ceplos begitu saja, ya nggak". Hore...! kata peserta sambil bertepuk tangan dari kelompok penengah yang turut serta meramaikan suasana.

Langkah ketiga, beliau meminta argumen dari juru bicara kelompok pembela untuk menyampaikan pembelaannya, yang diwakili oleh Ira Windawati dan berkata: "Apa yang disampaikan oleh kelompok penyaji (Pro) tadi itu benar. Kita harus bangga sebagai seorang muslim mempunyai negara yang berdasarkan Islam. Karena hal itu berarti mengikuti sunnah Rasulullah saw".

Pak H. Muhammad Kholil, S.Pd.I terkadang sengaja membuat debat antara kelompok kontra dengan kelompok pembela dan sesekali minta argumentasi dari kelompok penengah. Kemudian beliau mendorong kepada peserta lainnya untuk mencatat jawaban berbagai argumen dan bantahan yang disarankan kepada juru debat mereka, juga mendorong mereka untuk memberikan applaus (tepuk tangan) terhadap argumumen-argumen yang disampaikan oleh wakil atau juru bicara dari team mereka.

Ketika dianggap perdebatannya sudah cukup, beliau mengakhiri perdebatan tersebut dengan menggabungkan kembali kelompok-kelompok tersebut ke dalam satu lingkaran penuh. Kemudian beliau menyimpulkan dan memberikan komentar tentang permasalahan yang diajukan dalam perdebatan tersebut, lalu beliau membuat diskusi seluruh kelas tentang apa yang telah dipelajari oleh sisiwa tentang pengalaman debat itu dan kemudian merumuskan argumen-argumen terbaik yang telah dibuat oleh kedua kelompok debat penyaji dan kontra tersebut.

Sebelum pembelajaran ditutup, beliau meminta sekali lagi untuk memberikan applaus atas debat yang telah mereka lakukan dan akhirnya menutup pembelajaran dengan membaca hamdalah dan berdo'a bersama. 


\section{PENUTUP}

Setelah penulis mengadakan penelitian secara seksama terhadap obyek penelitian yang berkompeten dalam hal penelitian ini. Maka peneliti dapat menyimpulkan beberapa hal sebagai berikut:

1. Kedua Guru Pendidikan Agama Islam pada ketiga kelas yang diteliti, sebelum mengajar telah mempersiapkan kegiatan pembelajaran dengan berbagai aktifitas seperti membuat perangkat pembelajaran meliputi; Program Tahunan (Prota), Program Semester (Promes), Rencana Pelaksanaan Pembelajaran (RPP) dan bahan ajar yang akan diperdebatkan di kelas.

2. Dalam pelaksanaan pembelajaran, pada aspek Tarikh dan SKI di kelas XII Administrasi Perkanntoran dibagi ke dalam tiga kelompok yaitu pro/penyaji, kontra dan pembela. kelompok penyaji bertugas menyampaikan materi dan di tanggapi oleh kelompok kontra dan kelompok pembela bertugas untuk meluruskan jalannya perdebatan, begitu juga pada aspek Akhlak di kelas XI Multimedia dan aspek Akidah di kelas X Akuntansi. Dalam mengevaluasi kedua guru Pendidikan Agama Islam tersebut sudah cukup baik, karena sudah menggunakan instrumen dalam pola yang baru yaitu instrumen soal uraian tertulis untuk menilai aspek kognitif, instrumen pengamatan sikap dan minat untuk menilai aspek afektif dan instrumen penugasan untuk menilai aspek psikomotorik.

3. Faktor pendukung dalam pelaksanaan metode Active Debate ini barasal dari 'guru, siswa dan sarana prasarana'. Kedua guru Pendidikan Agama Islam sudah tersertifikasi sehingga keduanya sudah sering mendapatkan diklat tentang pemmbelajaran, semua siswa sudah terbiasa dengan debat tatkala belajar diasrama, 'Sarana prasarana' terutama bangku dan meja yang mudah di susun dalam formasi debate dan didukung adanya waifi, materi pelajaran didukung dari pelajaran yang diajarkan dipesantren, dan metode yang di gunakan di pesantren adalah metode sawir (musyawarah) juga bisa di katakana metode Devate. Dan faktor penghambat dalam pelaksanaan metode debat aktif ini adalah tidak semua guru mendukung, tidak ada respon yang positif dari pengurus yayasan dan adanya intimidasi dari siswa yang merasa tersudut.

\section{UCAPAN TERIMAKASIH}

Peneliti mengucapkan terimakasih kepada Sekolah Tinggi Keguruan Dan IImu Pendidikan dan LPPM STKIP Nurul Huda Sukaraja OKU Timur dan Tim Jurnal Al I'Tibar program studi Pendidika Agama Islam.

\section{DAFTAR PUSTAKA}

Abdussalam, Suroso 2012, Cara Mendidik Anak Sejak Lahir Hingga

TK, Sukses Publishing, Surabaya.

Achmadi 2005, Ideologi Pendidikan Isla., Pustaka Pelajar, Yoyakarta.

Arief, Ar 2002, Pengantar IImu dan Metodologi Pendidikan Islam.Ciputat, Pers Jakarta.

Arikunto, Suharsimi, at. al., 2006, Penelitinan Tindakan Kelas, Jakarta: Bumi Aksara. 
Arifin, M 1991, IImu Pendidikan Islam: Suatu Tinjauan Teoritis dan PraktisBerdasarkan Pendekatan Indisipliner.Bumi Aksara,Jakarta.

Arifin, Anwar 2003, Memahami Paradigma Baru Pendidikan Nasional dalam Undang Undang Sisdiknas. Ditjen Kelembagaan Agama Islam Depaq, Jakarta.

Aqib, Zainal 2013, Model-Model, Media dan Strategi Pembelajaran Kontekstual (Inovatif).Yrama Widya, Bandung.

Djamarah, Syaiful Bahri 2002, Psikologi Belajar. PT Rineka Cipta, Jakarta.

Djamarah, Syaiful Bahri dan Zain, Aswan 2010, Strategi Belajar Mengajar. Rineka Cipta, Jakarta.

Djajadisastra 1982, Metode-Metode Mengajar, Penerbit Angkasa, Bandung.

Faturrahman. Ahmadi, Khoiru et el 2012, Pengantar Pendidikan. PT Prestasi Pustakarya, Jakarta.

Halim, M. Nipan 2000, Anak Shaleh Dambaan Keluarga. Mitra Pustaka,Yogyakarta.

Hamalik, Oemar 2008, Perencanaan Pengajaran Berdasarkan Pendekatan Sistem. Bumi Akasara,Jakarta.

2001, Kurikulum dan Pembelajaran. PT. Bumi Aksara, Jakarta.

Hassbullah 2008, Dasar-dasar IImu Pendidikan. PT Raja Grafindo Persada, Jakarta.

Hernowo 2001, Mengikat Makna. Kaifa,Bandung.

Hery Noer Aly dan Munzier S., 2003, Watak Pendidikan Islam, Priska Agung Insani, Jakarta.

Hidayat, Komaruddin dalam Mel Silberman 2001, 101 Strategi Pembelajaran Aktif dalam Active Learning. YAPPENDIS, Yogyakarta.

Idi, Abdullah 2011, Sosiologi Pendidikan. Rajadrafindo Persada, Jakarta.

ISMKil, SM 2008, Strategi Pembelajaran Agama Islam Berbasis PAIKEM: Pembelajaran Aktif, Inovatif, Kreatif, Efektif, dan Menyenangkan. Rasail Media Group,Semarang.

Jacobsen, David A. Eggen, Paul et el 2009, Methods for Teaching. Metode-Metode Pengajaran Meningkatkan Belajar siswa TK - SMA. Pustaka Belajar, Yokyakarta.

Joyce, Bruce, dkk 2011, Models of Teaching (Model-Model Pengajaran). Pustaka Pelajar, Yogyakarta.

Kountur, Ronny 2009, Metode Penelitian Untuk Penulisan Skripsi dan Tesis. PPM, Jakarta.

Ma'arif, Syafi'i 1996, Ibnu Khaldun dalam Pandangan Penulis Barat dan Timur. Gema Insani Press,Jakarta.

Majid, Abdul 2005, Perencanaan Pembelajaran: Mengembangkan Standar 
kompetensi Guru. Remaja RosdaKarya,Bandung.

Moeleong, Lexy, J.M 2005, Strategi Penelitian Kualitatif. Remaja RosdaKarya, Cet. XIV, Bandung.

Moleong, Lexy J 2010, Metodologi Penelitian Kualitatif. PT Remaja Rosdakarya, Bandung.

Muhaimin, et el 2004, Paradigma Pendidikan Islam. PT. Remaja Rosdakarya,Bandung.

Mukti, Abdul 1998, dalam Chabib Thaha (eds), PBM-PAl di Sekolah, Eksistensi dan Proses Belajar Mengajar Pendidikan Agama Islam. Pustaka Pelajar dan Fakultas Tarbiyah IAIN Walisongo, Yogyakarta.

Muliawan, Jasa Ungguh 2005, Pendidikan Islam Integratif. Pustaka Pelajar,Yogyakarta.

2008, Kurikulum Tingkat Satuan Pendidikan(KTSP)Sebuah Panduan Praktis.PT. Remaja Rosdakarya,Bandung.

Mulyasa 2005, Kurikulum Berbasis Kompetensi. PT Remaja Rosdakarya, Bandung. 2009, Kurikulum Tingkat Satuan Pendidikan. PT Remaja Rosdakarya, Bandung.

2009, Implementasi Kurikulum Tingkat Satuan Pendidikan. PT Bumi Aksara, Jakarta.

—_ 2011, Menjadi Guru Profesional. PT Remaja Rosdakarya, Bandung.

Muslich, Mansur 2009, KTSP Pembelajaran Berbasis Kompetensi dan Kontektual.Bumi Aksara, Jakarta.

Muslim, Imam tt, Shahih Muslim Juz I. Syirkah Ma'arif Lithob'i Wannasyr,Bandung.

Naim dan Patoni 2007, Materi Penyusunan Desai Pembelajaran Pendidikan Agama Islam (MPDP-PAI. Pustaka Pelajar,Yoyakarta.

Nasih Ulwan, A 1981, Pedoman Pendidikan Anak dalam Islam, Jilid I. CV,Asy-Syifa', Semarang.

Nasution, S 2008, Asas-Asas Kurikulum. Bumi Aksara, Jakarta.

Ramayulis, H 2008, IImu Pendidikan Islam. Kalam Mulia, Jakarta.

Riduwan 2008, Metode dan Teknik Menyususn Tesis. Alfabeta, Bandung.

Rivai dan Sudjana 2001, Teknologi Pengajaran. Sinar Baru Algensindo, Bandung.

Roestiyah 2001, Strategi Belajar Mengajar. Penerbit Reneka Cipta, Jakarta.

Sanjaya, Wina 2008, Strategi Pembelajaran. Kencana Prenada Media Group, Jakarta.

Zuhaily, Wahbah1994, Tafsir Munir Juz XXX. Dar-al-Fikr al-Mu'ashir,Libanon. 